\title{
ПОРІВНЯЛЬНА ОЦІНКА НЕЙРОРЕТИНОПРОТЕКТИВНОЇ АКТИВНОСТІ АДЕМОЛУ ОКРЕМО ТА ЗА УМОВИ ЙОГО ПОЄДНАННЯ З МЕКСИДОЛОМ ПРИ ЇХ НАРІЗНОМУ ЗАСТОСУВАННІ В КОМПЛЕКСНІЙ ТЕРАПІЇ ПЕРЕХІДНОЇ ІШЕМІЇ ОКА ЩУРІВ ЗА ЗМІНАМИ МЕТАБОЛІЧНИХ ПРОЦЕСІВ У СІТКІВЦІ
}

\author{
ОІ. Л. Черешнюк, О. В. Ходаківська, О. А. Ходаківський, С. В. Прокопенко \\ Вінницький національний медичний університет імені М. І. Пирогова
}

РЕзЮМЕ. Актуальною задачею сучасної фармакології $€$ розробка препаратів на основі біологічно активних речовин, які можуть стати платформою для створення препаратів із нейроцитопротективною активністю для терапії ішемічних уражень зорового аналізатора.

Мета дослідження - вивчити вплив блокатора NMDA-рецепторів адемолу на метаболічні процеси в сітківці у гострий постреперфузійний період як можливий внутрішньоклітинний механізм нейроцитопротективної дії препарату та оцінити його ефективність у поєднанні з мексидолом при їх нарізному застосуванні в комплексній терапії цього стану.

Матеріали та методи. Терапевтичне застосування ампульного 1,0 \% розчину адемолу здійснювали умовноефективною дозою 2 мг/кг внутрішньоочеревинно упродовж першої доби гострого постреперфузійного періоду (накладання та подальше затягування ретробульбарних лігатур до зникнення кровотоку в судинах сітківки тривалістю 1 год) через кожні 12 год. Паралельно проводили комбіноване нарізне послідовне з інтервалом 10 хв уведення адемолу (2 мг/кг) та мексидолу (100 мг/кг) за аналогічною схемою. Останню ін'єкцію виконували за 1 год до завершення експерименту та евтаназії тварин.

Результати. Адемол дозою 2 мг/кг має комплексну корегувальну дію на порушені внутрішньоклітинні метаболічні процеси в сітківці щурів, що проявляється ліквідацією енергодефіциту (збереження пулу аденозинтрифосфорної кислоти, порівняно із контрольною патологією, в середньому на рівні 18,2 \%), антиоксидативним ефектом (зменшення маркерів перекисного окиснення ліпідів та окисної модифікації білків: рівнів малонового діальдегіду та карбонільних груп протеїнів, у середньому відповідно на 33,1 та 26,9 \% при паралельному наростанні активності глутатіонпероксидази на 36,0 \%, p<0,05) та модулювальним впливом на обмін монооксиду азоту за рахунок зменшення рівня стабільних метаболітів нітроген монооксиду в середньому на 58,0 \%. На тлі нарізного послідовного застосування адемолу (2 мг/кг) і мексидолу (100 мг/кг) у складі комплексної терапії ішемії-реперфузії ока щурів відмічається вірогідне потенціювання та сумація позитивних метаболітотропних явищ.

Висновки. Зазначені біохімічні зміни характеризують провідні метаболітотропні внутрішньоклітинні (нерецепторні) механізми нейроретинопротективної дії препарату. Отримані дані обґрунтовують доцільність подальшої доклінічної оцінки ефективності поєднання цих лікарських засобів у складі комплексної терапії даної патології та роблять перспективною можливість створення фіксованої комбінованої фармацевтичної композиції на їх спільній основі.

КлючОВІ СлОВА: адемол; мексидол; ішемія-реперфузія ока; сітківка.

Вступ. Відомо, що при ішемічно-гіпоксичних ураженнях сітківки один із перспективних векторів нейроретинопротекторної терапії - це блокада ранніх реакцій глутамат-кальцієвого каскаду. В даному випадку фокус цитопротективної терапії має всі підстави для свого зосередження на блокаторах NMDA-рецепторно-іонофорного комплексу нейронів. На сьогодні фармацевтичний ринок препаратів подібної спрямованості, дієвість яких в якості нейроретинопротекторів не доведена з позиції доказової медицини, що, власне, і не дає права провести правомірну екстраполяцію їх ефективності в офтальмологічній практиці до відповідних показань в інструкції за таким призначенням - номінально відсутній та несформований. Саме тому актуальною задачею сучасної фармакології $€$ розробка препаратів на основі біологічно-активних речовин, які можуть стати платформою для подібного проекту. Однак напрямок таких розробок досить складний, коштовний та тривалий, а здійснити його повною мірою можливо лише за умови тісної співпраці науковців різних галузей медицини із потужним фармацевтичним підприємством, яке може налагодити створення промислового зразка новоствореного препарату. Альтернативою у вирішенні даної проблеми може бути доклінічна оцінка вже відомих лікарських засобів із блокувальною дією на процес формування глутаматної ексайтотоксичності за новим призначенням в якості нейроцитопротекторів у розрізі саме офтальмологічної царини. Згідно з літературними даними, похідне адамантану адемол, якому притаманний модулювальний вплив на активність NMDA-рецепторів, має всі якості, які дозволяють розглядати його в площині нейроретинопротективної терапії. В умовах гострої церебральної ішемії, окрім антиексайтотоксичної дії, даний препарат має стимулюваль- 
Огляди літератури, оригінальні дослідження, погляд на проблему

ний вплив на кровопостачання головного мозку, сприяє ліквідації енергодефіциту, метаболічного ацидозу, оксидативного ушкодження нейронів та виявляє коригувальну дію на обмін монооксиду азоту. На сьогодні триває друга фаза клінічних випробовувань його ефективності у хворих із гострим порушенням мозкового кровотоку.

Наші попередні дослідження ефективності адемолу при ішемії сітківки також показали наявність вираженої нейроретинопротекторної активності, що проявилось у збереженні її цитоархітектоніки, у тому числі за рахунок зменшення апоптозу та процесів нейродеструкції $[1,2]$.

3 огляду на те, що, окрім глутаматної ексайтотоксичності, при ішемії сітківки мають місце зміни внутрішньоклітинного метаболізму (енергодефіцит, ацидоз, оксидативний та нітрозативний стрес тощо), доцільним є залучення до комплексної терапії метаболітотропних цитопротекторів. У попередніх роботах нами була встановлена виражена нейроретинопротекторна активність похідного бурштинової кислоти - мексидолу [3-5]. На нашу думку, доцільно, по-перше, охарактеризувати вплив адемолу на перебіг метаболічних процесів сітківки як одного із механізмів його нейроретинопротективної дії; по-друге - оцінити наявність ефекту потенціювання та сумації протективного ефекту на сітківку шляхом нарізного послідовного застосування в комплексній терапії разом із мексидолом. Згідно з наказом Міністерства охорони здоров'я України (МО3) № 944 від 14.12.2009 р. «Про затвердження Порядку проведення доклінічного вивчення лікарських засобів та експертизи матеріалів доклінічного вивчення лікарських засобів», окреме введення препаратів, які не піддаються механічному змішуванню з утворенням якісно нової фармацевтичної композиції, називається нарізним та характеризує саме поетапність комплексної терапії і не має за мету створення нового комбінованого лікарського засобу.

Мета дослідження - вивчити вплив блокатора NMDA-рецепторів адемолу на метаболічні процеси в сітківці у гострий постреперфузійний період як можливий внутрішньоклітинний механізм нейроцитопротективної дії препарату та оцінити його ефективність у поєднанні з мексидолом при їх нарізному застосуванні в комплексній терапії цього стану.

Матеріал і методи дослідження. Експерименти проведено на 40 щурах-самцях лінії Вістар масою 160-180 г. Усі тварини перебували у віварії Вінницького національного медичного університету імені М. І. Пирогова (ВНМУ) на стандартному водно-харчовому раціоні при природному освітленні та вільному доступі до води та корму. Під час робо- ти з лабораторними тваринами дотримувалися методичних рекомендацій державного фармацевтичного центру МO3 України і вимог біоетики згідно 3 національними «Загальними етичними принципами експериментів на тваринах» (2001), що відповідають положенням «Європейської конвенції про захист хребетних тварин, які використовуються для експериментальних та інших наукових цілей» $[6,7]$. Дотримання біоетичних норм засвідчено комітетом з біоетики ВНМУ імені М. І. Пирогова (витяг з протоколу № 12 від 10.12.2015).

Дослідження проводили в науково-дослідному центрі ВНМУ імені М. І. Пирогова (свідоцтво MO3 України про переатестацію № 003/10 від 11 січня 2010 р.) та на базі клінічно-діагностичної лабораторії кафедри біохімії (свідоцтво МОЗ України про переатестацію № 002/10 від 11 січня 2010 р.). Для відтворення модельної ішемії сітківки використовували модель однобічної ішеміїреперфузії (IP) ока у щурів шляхом накладання та подальшого затягування лігатури до зникнення кровотоку в судинах сітківки (термін експозиції 1 год). Через 60 хв після ішемії ретробульбарну лігатуру обережно розпускали і знімали - кровобіг у судинах ока відновлювався самостійно. Стан судин очного дна контролювали за допомогою прямої офтальмоскопії [8].

Досліджували промисловий зразок ампульного $1,0 \%$ розчину 1-адамантилетилокси-3морфоліно-2-пропанолу гідрохлориду («Адемол", Дарниця, Україна) для внутрішньовенних ін'єкцій, уводили внутрішньоочеревинно (в/о) дозою 2 мг/кг. Згідно з нашими власними даними, саме така доза $є$ умовно-ефективною терапевтичною при ішемічних ураженнях сітківки та сприяє реалізації максимальної нейроцитопротекторної дії препарату за даної патології [1, 2]. Аналогічним чином ми обґрунтували умовно-ефективну терапевтичну дозу для мексидолу (100 мг/кг, «Мексидол», НВК Фармасофт, Росія), встановивши оптимальні строки початку терапії обома препаратами [3-5]. Терапію адемолом розпочинали через 30 хв після накладання ретробульбарної лігатури з наступним його введенням з інтервалом 12 год (двічі на добу). В іншій групі тварин на тлі IP ока проводили комбіноване нарізне послідовне з інтервалом 10 хв уведення адемолу (2 мг/кг, в/о) та мексидолу (100 мг/кг, в/о) за аналогічною схемою. Останню ін'єкцію виконували за 1 год до завершення експерименту та евтаназії тварин.

Група контрольної патології (тварини з IP) та псевдооперовані щури отримували в якості об'ємної замісної терапії 0,9 \% розчин $\mathrm{NaCl}$ із розрахунку 2 мл/кг в/о.

Псевдооперованих щурів піддавали усім втручанням (наркоз, офтальмоскопія, накладан- 
Огляди літератури, оригінальні дослідження, погляд на проблему

ня ретробульбарної лігатури - за винятком її затягування). Травматичні маніпуляції та евтаназію тварин шляхом декапітації виконували в умовах пропофолового наркозу (60 мг/кг в/о) [9] («Fresenius Kabi», Австрія).

Зміни метаболічних показників у сітківці ока щурів оцінювали через 24 год після реканалізації. Сітківку промивали холодним 1,15 \% розчином $\mathrm{KCl}$ та гомогенізували у середовищі $1,15 \%$ розчину $\mathrm{KCl}$ (співвідношення 1:3). Постядерну фракцію отримували з гомогенатів шляхом центрифугування (30 хв, $1500 \mathrm{~g} \mathrm{при} \mathrm{+4} \mathrm{С).} \mathrm{Стан} \mathrm{енергетичного}$ та вуглеводного обміну в сітківці оцінювали за вмістом аденозинтрифосфорної кислоти (АТФ). Вміст АТФ визначали в безбілковому трихлороцтовому екстракті сітківки ока 1:5 (10\% розчин трихлороцтової кислоти) хроматографічним методом [10]. Вміст загального білка визначали мікробіуретовим методом з реактивом Бенедикта [11]. Інтенсивність оксидативного стресу в сітківці визначали за кінцевим продуктом процесу перекисного окиснення ліпідів (ПОЛ) - малоновим альдегідом (МДА), та показником окисної модифікації білка (ОМБ) - карбонільними групами протеїнів (КГП). Про кількість NO в сітківці судили за рівнем у гомогенатах стабільних метаболітів нітритів та нітратів.

Стан системи антиоксидантного захисту в сітківці оцінювали за активністю глутатіонпероксидази (ГПР). Вміст МА визначали за реакцією з тіобарбітуровою кислотою [12], КГП - за реакцією 3 2,4-динітрофенілгідразином [13]. Сумарний вміст нітритів та нітратів визначали за реакцією з реактивом Гріса після відновлення нітратів зависсю цинкового порошку в розчині амоніаку [14]. Активність ГПО визначали спектрофотометричним методом за накопиченням окисненого глутатіону [15].

Результати обробляли за допомогою статистичної програми StatPlus 2009. Використовували параметричний критерій $t$ Стьюдента та непара- метричний критерій W Уайта. Вірогідними вважали зміни при $\mathrm{p}<0,05$.

Результати й обговорення. Встановлено, що кінець першої доби постреперфузійного періоду ока у щурів супроводжувався розвитком виражених біохімічних змін у перебігу метаболічних процесів у клітинах сітківки, а саме, мало місце формування енергодефіциту, який верифікувався вірогідним відносно псевдооперованих тварин зниженням пулу АТФ в середньому на $47,6 \%$, наростали явища оксидативного стресу (підвищувався вміст МДА та КГП при паралельному зниженні активності ГПО в середньому відповідно у $1,98,1,81$ та 1,76 раза, $\mathrm{p}<0,05)$ та відмічався дисбаланс у системі монооксиду азоту (зростав вміст стабільних метаболітів нітроген монооксиду - нітритів та нітратів, - в середньому відповідно у $3,46$ раза, $p<0,05)$.

Нами виявлені вірогідні зміни досліджуваних критеріїв, які дають можливість говорити про притаманний адемолу коригувальний вплив на окреслені процеси в ретиноцитах. По-перше, у гострому постреперфузійному періоді терапевтичне застосування адемолу має позитивну енергомодулювальну дію, на користь чого свідчило збереження пулу АТФ в клітинах сітківки на рівні, на 18,2 \% вищому за аналогічний показник у тварин групи контрольної патології (табл. 1).

У щурів з IP, яким проводили нарізне послідовне застосування адемолу та мексидолу, приріст рівня АТФ в клітинах сітківки, порівняно з тваринами контрольної патології, становив в середньому $56,0 \%(p<0,05)$, що $\epsilon$ вірогідно вищим за ефект, притаманний монотерапії похідним адамантану, в середньому на $32 \%$.

Оцінюючи зміни на тлі експериментальної терапії у процесах оксидативного стресу ми дійшли до висновку, що у постреперфузійний період на тлі адемолу вміст у сітківці щурів маркерів ПОЛ та ОМБ, а саме МДА та КГП, був у середньому відповідно на 33,1 та $26,9 \%$ меншим $(p<0,05)$, ніж у тва-

Таблиця 1. Вплив лікувального введення адемолу та нарізного послідовного застосування адемолу і мексидолу у складі комплексної терапії ішемії-реперфузії ока щурів на пул аденозинтрифосфорної кислоти в сітківці станом на 24 год експерименту $(M \pm m, n=10)$

\begin{tabular}{|l|c|}
\hline \multicolumn{1}{|c|}{ Характеристика груп тварин } & АТФ (нмоль/мг протеїну) \\
\hline Псевдооперовані тварини + 0,9\% NaCl & $52,5 \pm 1,79$ \\
\hline Група контрольної патології (IP +0,9\% NaCI) & $27,5 \pm 1,52^{\circ}$ \\
\hline IP + адемол (2 мг/Кг) & $32,50 \pm 1,56^{\circ *}$ \\
\hline IP + адемол (2 мг/Кг)+ мексидол (100 мг/кг) & $42,9 \pm 1,71^{\circ * \#}$ \\
\hline
\end{tabular}

Примітки:

1. IP - ішемія-реперфузія;

2. ${ }^{\circ}$ - $\mathbf{p}<0,05$ відносно псевдооперованих тварин;

3. * - p<0,05 відносно контрольної патології;

4. ${ }^{*}$ - $p<0,05$ відносно адемолу. 
Огляди літератури, оригінальні дослідження, погляд на проблему

рин групи контрольної патології (табл. 2). Максимальний модулювальний вплив на оксидативний стрес виявлявся при нарізному послідовному використанні адемолу та мексидолу: рівні МДА та КГП в сітківці виявились меншими, порівняно з аналогічними показниками у щурів, яким вводили лише $0,9 \% \mathrm{NaCl}$ в середньому відповідно на 42,2 та 35,6\%, p<0,05 (табл. 1). Отже, за досліджуваними маркерами ефективність комплексної терапії адемолом та мексидолом вірогідно переважає монотерапію адамантаном в середньому в 1,16 та 1,13 раза.

Виявлено також, що фармакотерапія адемолом супроводжувалась вірогідним зростанням, відносно тварин групи контрольної патології, активності ГПО (в середньому на $36,0 \%$ ), що достеменно вказує на спроможність лікарського засобу суттєво запобігати виснаженню власної антиоксидантної системи сітківки, зберігаючи пул активності даного ензиму на високому рівні (табл. 2). Як і у попередньому випадку із маркерами оксидативного стресу, найпотужніший вплив на глутатіонпероксидазну систему в сітківці ока відмічався при нарізному послідовному застосуванні обох препаратів. За цих умов активність ГПО була вірогідно вищою в середньому на 53,7 \%, ніж в групі тварин контрольної патології, і переважала монотерапію адемолом в середньому на 13,0 \% (табл. 3).

Оцінюючи показники системи обміну монооксиду азоту можна зробити висновок, що фармакотерапія постреперфузійного ураження сітківки препаратом Адемол стримує формування нітрозативного стресу, справляючи депримуючий (пом'якшувальний) вплив на продукцію нітроген монооксиду, а значить і послаблює цитотоксичний ефект реакційноздатного пероксинітриту. У тварин, які отримували адемол, сумарний вміст нітритів та нітратів у сітківці був вірогідно меншим (в середньому на 40,0\%), порівняно зі щурами групи контрольної патології (табл. 4).

Нарізне послідовне введення адемолу та мексидолу виявляє максимальний вплив на продукцію нітроген монооксиду, про що опосередковано свідчило вірогідне зменшення в сітківці, порівняно із контрольною патологією, рівня ста-

Таблиця 2. Вплив лікувального введення адемолу та нарізного послідовного застосування адемолу і мексидолу у складі комплексної терапії ішемії-реперфузії ока щурів на рівень маркерів перекисного окиснення ліпідів та окисної модифікації білків у сітківці станом на 24 год експерименту ( $\mathrm{M} \pm \mathrm{m}, \mathrm{n}=10)$

\begin{tabular}{|c|c|c|}
\hline \multirow[b]{2}{*}{ Дослідні групи } & \multicolumn{2}{|c|}{ Показники } \\
\hline & $\begin{array}{c}\text { МДА, } \\
\text { нмоль/мг протеїну }\end{array}$ & $\begin{array}{c}\text { КГП, } \\
\text { нмоль/мГ протеїну }\end{array}$ \\
\hline Псевдооперовані тварини + 0,9% NaCl & $3,32 \pm 0,12$ & $1,15 \pm 0,06$ \\
\hline Група контрольної патології, IP +0,9% NaCl & $6,58 \pm 0,18^{\circ}$ & $2,08 \pm 0,09^{\circ}$ \\
\hline IP + адемол (2 мг/кг) & $4,40 \pm 0,21^{\circ *}$ & $1,52 \pm 0,060 *$ \\
\hline IP + адемол (2 мг/кг) + мексидол (100 мг/кг) & $3,80 \pm 0,170 * \#$ & $1,34 \pm 0,05^{\circ * \#}$ \\
\hline
\end{tabular}

Примітки:

1. IP - ішемія-реперфузія; МДА - малоновий діальдегід; КГП - карбонільні групи протеїнів;

2. ${ }^{\circ}-$ р $<0,05$ відносно псевдооперованих тварин;

3. * - $<<0,05$ відносно контрольної патології;

4. " - p<0,05 відносно адемолу.

Таблиця 3. Вплив лікувального введення адемолу та нарізного послідовного застосування адемолу і мексидолу у складі комплексної терапії ішемії-реперфузії ока щурів на активність глутатіонпероксидази в сітківці станом на 24 год експерименту ( $\pm \pm m, n=10)$

\begin{tabular}{|l|c|}
\hline \multicolumn{1}{|c|}{ Дослідні групи } & ГПО (мкмоль/хв на 1 мг протеїну) \\
\hline Псевдооперовані тварини + 0,9\% NaCl & $5,68 \pm 0,21$ \\
\hline $\begin{array}{l}\text { Група контрольної патології } \\
\text { IP +0,9\% NaCl }\end{array}$ & $3,22 \pm 0,17^{\circ}$ \\
\hline IP + адемол (2 мг/кг) & $4,38 \pm 0,18^{\circ *}$ \\
\hline IP + адемол (2 мг/кг) + мексидол (100 мг/кг) & $4,95 \pm 0,17^{\circ * \#}$ \\
\hline
\end{tabular}

Примітки:

1. IP - ішемія-реперфузія;

2. ${ }^{\circ}$ - $\mathrm{p}<0,05$ відносно псевдооперованих тварин;

3. * - p<0,05 відносно контрольної патології;

4. ${ }^{*}$ - $p<0,05$ відносно адемолу. 
Огляди літератури, оригінальні дослідження, погляд на проблему

Таблиця 4. Вплив лікувального введення адемолу та нарізного послідовного застосування адемолу і мексидолу у складі комплексної терапії ішемії-реперфузії ока щурів на сумарний вміст нітритів та нітратів у сітківці станом на 24 год експерименту $(M \pm m, n=10)$

\begin{tabular}{|l|c|}
\hline \multicolumn{1}{|c|}{ Дослідні групи } & Нітрати та нітрити (нмоль/мг протеїну) \\
\hline Псевдооперовані тварини + 0,9\% NaCl & $5,35 \pm 0,19$ \\
\hline $\begin{array}{l}\text { Група контрольної патології } \\
\text { (IP +0,9\% NaCI) }\end{array}$ & $18,5 \pm 0,24^{\circ}$ \\
\hline IP + адемол (2 мг/кг) & $11,1 \pm 0,27^{* *}$ \\
\hline IP + адемол (2 мг/Кг)+ мексидол (100 мг/кг) & $7,78 \pm 0,23^{\circ * \#}$ \\
\hline
\end{tabular}

Примітки:

1. IP - ішемія-реперфузія;

2. ${ }^{\circ}-\mathrm{p}<0,05$ відносно псевдооперованих тварин;

3. * - р<0,05 відносно контрольної патології;

4. ${ }^{*}$ - $\mathrm{p}<0,05$ відносно адемолу.

більних метаболітів нітроген монооксиду в середньому на 58,0 \%, перевершуючи монотерапію адемолом у 1,43 раза (див. табл. 4).

Проведене дослідження показало, що адемол чинить виражений вплив на формування енергодефіциту, розвиток оксидативного стресу, обмін монооксиду азоту (нітрозативний стрес), що $є$ одним із внутрішньоклітинних (нерецепторних механізмів) нейроретинопротективної дії препарату. При цьому на тлі нарізного послідовного застосування адемолу і мексидолу у складі комплексної терапії IP ока щурів відмічається вірогідне потенціювання та сумація позитивних метаболітотропних явищ на рівні досліджуваних маркерів.

Висновки. Терапевтичне застосування ампульного 1,0 \% розчину адемолу умовно-ефективною дозою 2 мг/кг в/о у гострий постреперфузійний період має комплексну корегувальну дію на порушені внутрішньоклітинні метаболічні процеси в сітківці щурів, що виявляється ліквідацією енергодефіциту (збереження пулу АТФ, порівняно із контрольною патологією, в середньому на рівні 18,2 \%), антиоксидантним ефектом (зменшення маркерів ПОЛ та ОМБ, а саме рівнів МДА та КГП, в середньому на 33,1 та 26,9 \%, на тлі паралельного зростання активності ГПО відповідно на 36,0 \%, p<0,05) та модулювальним впливом на обмін монооксиду азоту за рахунок зменшення рівня стабільних метаболітів нітроген моноокси- ду в середньому на 58,0 \%. Зазначені біохімічні зміни характеризують провідні метаболітотропні внутрішньоклітинні (нерецепторні) механізми нейроретинопротективної дії препарату.

2. На тлі нарізного послідовного застосування адемолу і мексидолу у складі комплексної терапії IP ока щурів відмічається вірогідне потенціювання та сумація позитивних метаболітотропних явищ на рівні досліджуваних маркерів, що обґрунтовує подальшу доклінічну оцінку ефективності поєднання цих препаратів у складі комплексної терапії ішемії-реперфузії ока та робить перспективною оцінку можливості створення фіксованої комбінованої фармацевтичної композиції на їх спільній основі.

Перспективи подальших досліджень. Провести подальшу доклінічну оцінку нейроретинопротекторних властивостей адемолу для підготовки повноцінного досьє на проведення клінічних випробовувань ефективності препарату при ішемічних ураженнях зорового аналізатора. Застосовуючи квантово-хімічні методи можливої взаємодії адемолу та мексидолу, оцінити можливість створення фіксованої комбінованої фармацевтичної композиції на основі двох препаратів. Продовжити доклінічну оцінку ефективності нарізного послідовного застосування адемолу і мексидолу у складі комплексної терапії ішемії-реперфузії ока на предмет доцільності клінічних випробовувань даної схеми.

\section{ЛІТЕРАТУРА}

1. Черешнюк І. Л. Характеристика нейроретинопротекторних властивостей адемолу за морфологічними змінами сітківки та зорового нерва при експериментальній ішемії-реперфузії ока на тлі алоксанового цукрового діабету / І. Л. Черешнюк, О. А. Ходаківський, Г. В. Загорій // Інтегративна антропологія. - 2015. - № 2. - С. 51-55.
2. Черешнюк І. Л. Ефективність адемолу у постреперфузійний період тотальної ішемії ока крізь призму засад сучасної нейроретинопротективної терапії / І. Л. Черешнюк // Вісник Вінницького національного медичного університету. - 2015. - Т. 19, № 1. - С. 14-20.

3. Черешнюк І. Л. Особливості перебігу метаболічних процесів у сітківці щурів в умовах гострої ішемії-ре- 
Огляди літератури, оригінальні дослідження, погляд на проблему

перфузії ока (характеристика моделі) та оцінка ретинопротекторних властивостей мексидолу / І. Л. Черешнюк, Г. В. Загорій, О. А. Ходаківський // Буковинський медичний вісник. - 2015. - Т. 19, № 4. - С. 193-197.

4. Цереброваскулярные эффекты блокаторов NMDA-рецепторов и мексидола на фоне аллоксанового сахарного диабета, а также их влияние на течение метаболических процессов в сетчатке монгольских песчанок в острый постперфузионный период / И. Л. Черешнюк, В. Л. Повх, Г. В. Загорий, А. А. Ходаковский // Врач-аспирант. - 2016. - Т. 74, № 1.2. - С. 295-303.

5. Черешнюк І. Л. Нейроретинопротекторні властивості мексидолу в умовах перехідної ішемії ока / І. Л. Черешнюк, Г.В.Загорій, О.А.Ходаківський // Biomedical and Biosocial Anthropology. - 2015. - № 24. - C. 90-92.

6. Директива Совета ЕС о сближении законов, постановлений и администрирование положений государств ЕС по вопросам защиты животных, используемых для экспериментальных и других научных целей (86/609/EEC) // В кн. : Надлежащая производственная практика лекарственных средств / под ред. Н. А. Ляпунова, В. А. Загория, В. П. Георгиевского, Е. П. Безуглой. - К. : Морион, 1999. - С. 508-545.

7. Simone F. Biotechnology, animal health and animal welf are within the framework of European Unionlegislation / F. Simone, J. Serratosa // Rev. Sci. Tech. Oie. - 2005. - Vol. 24, № 1. - P. 89-99.

8. Minhas G. Preclinical models to investigate retinal ischemia:advances and drawbacks/G. Minhas, R. Morishita, A. Anand // Front Neurol. - 2012. - Vol. 3. - P. 75.

\section{REFERENCES}

1. Chereshniuk, I.L., Khodakivskyi, O.A. \& Zahorii, H.V. (2015). Kharakterystyka neiroretynoprotektornykh vlastyvostei ademolu za morfolohichnymy zminamy sitkivky ta zorovoho nerva pry eksperymentalnii ishemiireperfuzii oka na tli aloksanovoho tsukrovoho diabetu [Characteristics of ademol neuroprotective properties according to morphological changes in the retina and optic nerve in experimental ischemia-reperfusion eye on the background of aloxite diabetes]. Intehratyvna antropolohiia - Integrative Anthropology, 2, 51-55 [in Ukrainian].

2. Chereshniuk, I.L. (2015). Efektyvnist ademolu u postreperfuziinyi period totalnoi ishemii oka kriz pryzmu zasad suchasnoi neiroretynoprotektyvnoi terapii [Efficiency of ademol in post-reperfusion total period of ischemia of the eye in the light of the principles of modern neuroprotective therapy]. Visnyk Vinnytskoho natsionalnoho medychnoho universytetu - Journal of Vinnytsia National Medical University, 1 (19), 14-20 [in Ukrainian].

3. Chereshniuk, I.L., Zahorii, H.V., \& Khodakivskyi, O.A. (2015). Osoblyvosti perebihu metabolichnykh protsesiv u sitkivtsi shchuriv v umovakh hostroi ishemii-reperfuzii oka (kharakterystyka modeli) ta otsinka retynoprotektornykh vlastyvostei meksydolu [Peculiarities of metabolic processes in the retina of rats in acute ischemia-
9. Ходаківський О. А. Патогенетичне обґрунтування доцільності використання нових похідних адамантану при експериментальній терапії гострої ішемії головного мозку та міокарда (експериментальне дослідження) : автореф. дис. на здобуття наукового ступеня д-р. мед. наук : спец. 14.03.05 - фармакологія / О. А. Ходаківський. - Одеса, 2014. - 24 с.

10. Прохорова М. И. Современные методы биохимических исследований (липидный и энергетический обмен) / М. И. Прохорова. - Ленинград : Изд-во Ленинградского университета, 1982. - 272 с.

11. Кочетов Г. А. Практическое руководство по энзимологии / Г. А. Кочетов. - М. : Высшая школа, 1980. -272 c.

12. Владимиров Ю. В. Перекисное окисление липидов в биологических мембранах / Ю. В. Владимиров, А. И. Арчаков. - М. : Наука, 1972. - 252 с.

13. Заїчко Н. В. Окислювальна модифікація білків сироватки крові як маркер активності ревматоїдного артриту та їі зміни під впливом фармакотерапії амізоном, індометацином, німесулідом / Н. В. Заїчко // Вісник Вінницького національного медичного університету. - 2003. - № 7. - С. 664-666.

14. Коренман И. М. Методы определения органических соединений / И. М. Коренман. - М. : Химия, 1975. $-360 \mathrm{c}$.

15. ВласоваС.Н.Активностьглутатионзависимых ферментов эритроцитов при хронических заболеваниях печени у детей / С. Н. Власова, Е. И. Шабунина, И. А. Перслегина // Лаб. дело. - 1990. - № 8. - C. 19-22.

reperfusion of the eye (of the model) and evaluation of retino-protective properties of mexidol]. Bukovynskyi medychnyi visnyk - Bukovynian Medical Journal, 4 (19), 193197 [in Ukrainian].

4. Chereshniuk, I.L., Povkh, V.L., Zahorii, H. V., \& Khodakivskyi, O. A. (2016). Tserebrovaskulyarnye effekty blokatorov NMDA-retseptorov i meksydola na fone alloksanovogo sakharnogo diabeta, a takzhe ikh vliyanye na techenye metabolicheskikh protsessov v setchatke mongolskikh peschanok v ostryy postperfuzionnyy period [Cerebrovascular effects of NMDA receptors and mexidol blockers on the background of alloxanic diabetes mellitus, as well as their effect on the course of metabolic processes in the retina of Mongolian gerbils in the acute postperfusion period]. Vrach-aspirant - Doctor-postgraduate, 74 (1.2), 295-303. [in Russian].

5. Chereshniuk, I.L., Zahorii, H.V. \& Khodakivskyi, O.A. (2015). Neyroretynoprotektorni vlastyvosti meksydolu v umovakh perekhidnoi ishemii oka [Neuroprotective properties of mexidol in conditions of eye ischemia]. Biomedical and Biosocial Anthropology, 24, 90-92 [in Ukrainian].

6. Liapunova, N.A., Zagoriya, V.A., Georgiyevskiy, V.P., \& Bezuglaya, E.P. (Eds.). (1999). Dyrektyva Soveta ES o sblizhenii zakonov, postanovlenyy i administrirovanye polozhenyy gosudarstv ES po voprosam zashchity 
Огляди літератури, оригінальні дослідження, погляд на проблему

zhyvotnykh, ispolzuemykh dlya eksperementalnykh i drugikh nauchnykh tseley (86/609/EES) [Council of the EU Directive on alignment of laws, decrees and EU states to Administrative provisions On the issue of animal protection USED experimental for the Scientific and second goals (86/609 / EEC)]. Kyiv: "Moryon" [in Russian].

7. Simone, F. \& Serratosa, J. (2005). Biotechnology, animal health and animal welf are within the framework of European Unionlegislation. Rev. Sci. Tech. Oie., 24, 89-99.

8. Minhas, G., Morishita, R. \& Anand, A. (2012). Preclinical models to investigate retinal ischemia: advances and drawbacks. Front Neurol., 3, 75.

9. Khodakivskyi, O.A. (2014). Patohenetychne obhruntuvannia dotsilnosti vykorystannia novykh pokhidnykh adamantanu pry eksperymentalnii terapii hostroi ishemii holovnoho mozku ta miokarda (eksperymentalne doslidzhennia) [Pathogenetic rationale for the use of new adamantane derivatives in experimental therapy in acute cerebral ischemia and infarction (experimental study)]. Abstract of Doctor's thesis. Odesa [in Ukrainian].

10. Prokhorova, M.Y. Sovremennye metody biokhimicheskykh issledovaniy (lipidnyy i energeticheskiy obmen) [Modern methods of biochemical studies (lipid and energetic metabolism)]. Leningrad: Izd-vo Leningradskogo universiteta, 1982. [in Russian].
11. Kochetov H. A. (1980). Prakticheskoe rukovodstvo po enzimologii [Practical guidance on enzymology]. Moscow: Vysshaya shkola [in Russian].

12. Vladimirov, Yu.V. \& Archakov, A.Y. (1972). Perekysnoe okyslenie lipidov $v$ biologicheskikh membranakh [Peroxidation of lipids in biological membranes]. Moscow: Nauka [in Russian].

13. Zaichko, N.V. Okysliuvalna modyfikatsiia bilkiv syrovatky krovi yak marker aktyvnosti revmatoidnoho artrytu ta yii zminy pid vplyvom farmakoterapii amizonom, indometatsynom, nimesulidom [Oxidative modification of proteins of blood serum as a marker of rheumatoid arthritis activity and its changes under the influence of pharmacotherapy with Amizon, Indomethacin, Nimesulide]. Visnyk Vinnytskoho natsionalnoho medychnoho universytetu - Journal of Vinnytsia National Medical University, 7, 664-666 [in Ukrainian].

14. Korenman, I.M. Metody opredeleniya organicheskikh soedineniy [Methods for the determination of organic compounds]. Moscow: Khimiya [in Russian].

15. Vlasova, S.N., Shabunina, E.I. \& Perslegina, I.A. (1990). Aktyvnost glutatyon-zavisimykh fermentov eretrotsytov pri khronicheskikh zabolevaniyakh pecheni $u$ detey [Activity of glutathione-dependent erythrocyte enzymes in chronic liver diseases in children]. Lab. delo. Laboratory Case, 8, 19-22 [in Russian].

\title{
СРАВНИТЕЛЬНАЯ ОЦЕНКА НЕЙРОРЕТИНОПРОТЕКТОРНОЙ АКТИВНОСТИ АДЕМОЛА ОТДЕЛЬНО И ПРИ ЕГО СОЧЕТАНИИ С МЕКСИДОЛОМ ПРИ ИХ РАЗДЕЛЬНОМ ПРИМЕНЕНИИ В КОМПЛЕКСНОЙ ТЕРАПИИ ПЕРЕХОДНОЙ ИШЕМИИ ГЛАЗА КРЫС ПО ИЗМЕНЕНИЯМ МЕТАБОЛИЧЕСКИХ ПРОЦЕССОВ В СЕТЧАТКЕ
}

\author{
๑И. Л. Черешнюк, О. В. Ходаковская, А. А. Ходаковский, С. В. Прокопенко
}

\author{
Винницкий национальный медицинский университет имени Н. И. Пирогова
}

РЕЗЮМЕ. Актуальной задачей современной фармакологии является разработка препаратов на основе биологически активных веществ, которые могут стать платформой для создания препаратов с нейроцитопротекторной активностью для терапии ишемических поражений зрительного анализатора.

Цель исследования - изучить влияние блокатора NMDA-рецепторов адемола на метаболические процессы в сетчатке в острый постреперфузионный период как возможный внутриклеточный механизм нейроцитопротекторного действия препарата и оценить его эффективность в сочетании с мексидолом при их раздельном применении в комплексной терапии этого состояния.

Материалы и методы. Терапевтическое применение ампульного 1,0 \% раствора адемола осуществляли в условно-эффективной дозе 2 мг/кг внутрибрюшинно в течение первых суток острого постреперфузионного периода (наложение и дальнейшее затягивание ретробульбарных лигатур до исчезновения кровотока в сосудах сетчатки продолжительностью 1 ч) через каждые 12 часов. Параллельно проводили комбинированное раздельное последовательное с интервалом 10 мин введение адемола (2 мг/кг) и мексидола (100 мг/кг) по аналогичной схеме. Последнюю инъекцию выполняли за 1 ч до завершения эксперимента и эвтаназии животных.

Результаты исследований. Адемол в дозе 2 мг/кг проявляет комплексное корректирующее действие на нарушенные внутриклеточные метаболические процессы в сетчатке крыс, что проявляется ликвидацией энергодефицита (сохранение пула аденозинтрифосфорной кислоты, по сравнению с контрольной патологией, в среднем на уровне 18,2 \%), антиоксидантным эффектом (уменьшение маркеров перекисного окисления липидов и окислительной модификации белков: уровней малонового диальдегида и карбонильных групп белков в среднем соответственно на 33,1 и 26,9 \% при одновременном нарастании активности глутатионпероксидазы на $36,0 \%, p<0,05)$ и модулирующим влиянием на обмен монооксида азота за счет уменьшения уровня стабильных метаболитов нитроген монооксида в среднем на 58,0 \%. На фоне раздельного применения адемола (2 мг/кг) 
Огляди літератури, оригінальні дослідження, погляд на проблему

и мексидола (100 мг/кг) в составе комплексной терапии ишемии-реперфузии глаза отмечается достоверная потенциация и суммирование положительных метаболитотропных эффектов препаратов.

Выводы. Указанные биохимические изменения характеризуют ведущие метаболитотропные внутриклеточные (нерецепторные) механизмы нейроретинопротекторного действия препарата. Полученные данные обосновывают целесообразность дальнейшей доклинической оценки эффективности сочетания этих лекарственных средств в составе комплексной терапии данной патологии и делают перспективной возможность создания фиксированной комбинированной фармацевтической композиции на их общей основе.

КЛЮчЕВЫЕ СЛОВА: адемол; мексидол; ишемия-реперфузия глаза; сетчатка.

\title{
COMPARATIVE EVALUATION OF NEURORETINOPROTECTIVE ACTIVITY OF ADEMOLE AS MONOTHERAPY AND COMBINED WITH MEXIDOL (SEPARATE USAGE) IN COMPLEX THERAPY OF EYE TRANSITIONAL ISCHEMIA IN RATS BASED ON CHANGES OF METABOLIC PROCESSES IN RETINA
}

\author{
@I. L. Chereshniuk, O. V. Khodakivska, O. A. Khodakivskyi, S. V. Prokopenko \\ M. Pyrohov Vinnytsia National Medical University
}

Introduction. The actual task of modern pharmacology is the development of drugs based on biologically active substances, which can become a platform for creating news drugs with neurocytoprotective activity in the therapy of ischemic lesions of the visual analyzer (ILVA).

The aim of the study - to examine the effect of a blocker of NMDA-receptor ademol on metabolic processes in the retina in acute postreperfusion period as possible intracellular mechanism of neuroretinoprotective action of the drug and evaluate its effectiveness in combination with mexidol in the complex therapy of (ILVA).

Materials and Methods. Therapeutic use of an ampoule $1.0 \%$ ademol solution at conventionally effective dose of $2 \mathrm{mg} / \mathrm{kg}$ intraperitoneally, every 12 hours during the first day of acute post-reperfusion period (the application and further tightening of retrobulbar ligatures to a stop of blood flow in retinal vessels with an exposure time of 1 hour). In parallel, a combined separate sequential administration of ademol $(2 \mathrm{mg} / \mathrm{kg})$ and mexidol (100 mg/kg) was performed with an interval of 10 minutes in a similar scheme. The last injection was performed in 1 hour before the completion of the experiment and euthanasia of the animals.

Results. Ademol at a dose of $2 \mathrm{mg} / \mathrm{kg}$, exhibits a complex corrective effect on impaired intracellular metabolic processes in the retina, which is manifested by the elimination of energy deficiency (preservation of the adenosine triphosphate acid pool in comparison with the control pathology at the level of $18.2 \%$ ), antioxidative effect ( 33.1 and $26.9 \%$ decrease in the level of markers of peroxide oxidation of lipids and oxidative modification of proteins: malonic dialdehyde and carbonyl groups of proteins, respectively, with a simultaneous increase in the activity of glutathione peroxidase by $36.0 \%, \mathrm{p}<0.05$ ) and a modulating effect on the exchange of nitrogen monoxide by reducing the level of stable metabolites of nitrogen monoxide by an average of $58.0 \%$. On the background of separate sequential application of ademol $(2 \mathrm{mg} / \mathrm{kg})$ and mexidol $(100 \mathrm{mg} / \mathrm{kg})$ as a part of the complex therapy of ischemia-reperfusion of the rat eye, significant potentiation and summation of positive metabolitotropic phenomena at the level of the test markers is noted.

Conclusions. The above-mentioned biochemical changes characterize the leading metabolitotropic intracellular (non-receptor) mechanisms of the neuroretinoprotective action of the drug. The obtained data justify the expediency of further preclinical evaluation of the effectiveness of ademol-mexidol combination in the complex therapy of ILVA and make it promising to create a combined pharmaceutical composition.

KEY WORDS: ademol; mexidol; ischemia-reperfusion of the eye; retina. 